\title{
The Relationship between Job Characteristics and Transformational Leadership on Organization and Altruism Commitments and its Effects on Nurses' Satisfaction and Performance in Private Hospitals of Samarinda City
}

\author{
Supriadi $^{1,2}$, Sri Mintarti ${ }^{2}$, Ardi Paminto ${ }^{2}$, Tetra Hidayati ${ }^{2}$, Sukri Palutturi $^{3 *}$ \\ ${ }^{1}$ Health Polytechnic of the Ministry of Health of East Kalimantan \\ ${ }^{2}$ Faculty of Economics and Business Universitas Mulawarman, Indonesia \\ ${ }^{3}$ Faculty of Public Health Universitas Hasanuddin, Indonesia
}

*Corresponding Author

Sukri Palutturi

\section{Article History}

Received: 26.02 .2020

Accepted: 05.03.2020

Published: 11.03.2020

\begin{abstract}
The purpose of this study was to analyze and prove the relationship of Job Characteristics and Transformational Leadership on Organizational Commitment and Altruism and Its Effect on Nurses' Satisfaction and Performance in Private Hospitals in Samarinda City. The design of this study was explanatory research. The type of this research was observational study using a cross-sectional research design. The method used to collect the data in this study was survey method. The population of this study was nurses at Private Hospitals in Samarinda City. In this study, Slovin formula was used as the sampling method obtaining total of 225 respondents, while the data collection process used simple random sampling. This study used Structural Equation Modeling Partial Least Square (SEM-PLS) approach to analyze the data. The results of this study can be summarized as follows: Job characteristics provide a positive and significant effect on nurses' organizational commitment. Job characteristics provide a positive but not significant effect on nurses' satisfaction. Job characteristics have a positive but not significant effect on nurses' performance. Job characteristics have a positive and significant effect on nurses' altruism. Transformational leadership has a positive and significant effect on nurses' organizational commitment. Transformational leadership has a negative but not significant effect on nurses' satisfaction. Transformational leadership has a positive and significant effect on nurses' performance. Transformational leadership has a positive but not significant effect on nurses' altruism. Organizational commitment has a positive and significant effect on nurses' satisfaction. Organizational commitment has a positive and significant effect on nurses' performance. Altruism has a negative and insignificant effect on nurses' satisfaction. Altruism has a positive and significant effect on nurses' performance. Nurses' satisfaction provides a positive and significant effect on the performance of executive nurses at Private Hospitals in the City Samarinda.
\end{abstract}

Keywords: Job Characteristics, Transformational Leadership, Organizational Commitment, Altruism, Satisfaction, Nurses' Performance.

\section{INTRODUCTION}

Characteristics of nurses' duty in Private Hospitals in Samarinda City based on the researchers' observation is that the duty of the executive nurses is stated in the nurses' job description according to the level of authority of the Clinical Nurse (PK) 1, PK 2, PK 3 for nurses with Diploma 3 background in nursing and up to PK 4 for nurses whose education reaches a Bachelor's degree. An increase in clinical nurse position is carried out every 4 years, but begins with an annual appraisal of DP3K (List of Assessment, Implementation, and Employment Work) and a clinical nurse promotion [1]. The responsibilities of nurses have been clearly stated in the job description and in the implementation of the nurses' duties under the supervision of a nurse supervisor/team leader during the task implementation [2-4]. The nurses working hours is 8 hours with 3 shifts, in which the duties that should be done by the nurses include nursing care with the main work is fulfilling the patients' needs (performing basic care), implementing autonomy for nurses that can

Copyright @ 2020: This is an open-access article distributed under the terms of the Creative Commons Attribution license which permits unrestricted use, distribution, and reproduction in any medium for non commercial use (NonCommercial, or CC-BY-NC) provided the original author and source are credited. 
only be done in parts, and doing abundant tasks from other professionals/doctors such as giving injection. The executive nurses' duties are controlled by the team leader and also by the head of the ward. Nursing career paths have not been fully implemented, especially when referring to the Ministry of Health's nurse career paths.

Leadership policy related to its role in achieving the hospital's vision through nurses is the implementation of nurses' duty which is started by pre-conference (briefing) related to daily work plans and ended by post-conference and job changes at shifts. The role models given by superiors are still not optimal because there are hospitals that are only 5 years old so that the team leader and the head of the ward only have 5 years working experience at most and about $70 \%$ of the nurse's working period is less than 2 years. The implementation of the duties carried out is supervised by the team leader in which not all the nurses get a chance for nursing training. Hospital rules are open for staff to know. Counseling at the hospital is carried out in stages from the ward to the nursing committee, depending on the severity of the problem. Furthermore, the application of behavior as a nurse was observed by the work team leader during the duties implementation and the team leader was on every shift (Morning, Afternoon and Evening shifts). During the implementation of the duties of collaboration between team members, the interaction with the team leader refers to the rules of implementing the team assignment method in nursing services that emphasizes input, feedback, supervision, conference, and evaluation of the implementation process of nursing tuition which are carried out simultaneously and continuously $[5,6]$.

There is also a problem with the organizational commitment of nurses [7-10]. It can be found that there are nurses who just worked for 2-3 months and resigned. The reasons of thei resignment are various, including seeking experience in a hospital which is considered better, less reward and continuing education. Reasons for nurses of being still staying at the hospital also various including that they still want to look for experience, feel comfortable with the work and the working place which is close to their residence.

The nurses' performance in private hospitals in Samarinda City is still in standard level because nurse input also has standard competence. Some of the nurses who have worked since the Hospital established have been showing good performance, while nurses who have a working period of less than 2 years perform basic competency standards. There is $60-70 \%$ of nurses with a working period of less than 2 years. Nurses' duties productivity/nurse performance is measured by the service delivery process so that it is seen from the number of work items that are not done, complaints and KTD (undesirable events). Performance measurements are taken from the DP3K, in addition, nurses' productivity can be seen from the low absenteeism, and the incidence of negligence by nurses while on duty.

The nurses' performance in private hospitals is also still not running $100 \%$ as expected. It was proven that there were 2 nurses sentenced to 2 years in prison in Aceh hospitals related to cases of alleged wrongful injection of patients. This can be a reference and a reminder that it does not rule out the possibility of nurses in Samarinda City hospitals due to the same duty within the nursing environment and the same workload between one nurse and another nurse.

This research aimed to analyse the relationship between job characteristics and transformational leadership on organization and altruism commitments and its effects on nurses' satisfaction and performance in private hospitals of Samarinda City.

\section{Materilas ANd Methods Population and Samples}

The population in this study was all nurses in Private Hospitals in Samarinda City consisting of Dirgahayu Hospital, Bhakti Nugraha Hospital, and Samarinda Medika Citra Hospital. The sampling technique was done using proportionate stratified random sampling technique $[11,12]$. The sample of this study was the executive nurses in Private Hospitals in Samarinda City consisting of Dirgahayu Hospital and Samarinda Medika Citra Hospital totaling of 515 samples. The author used the size of the Slovin formula. Based on the overall sample, then the number of samples for each class of nurses was proportionally calculated, and then the sample stratafication was arranged that the number of questionnaires distributed was for 225 respondents in accordance with the number of samples in this study. The process of collecting data used simple random sampling.

\section{Data Analysis Technique}

In this study, the data analysis used a partial least square (PLS) approach[13, 14, 15]. Partial least square analysis (PLS) is a multivariate statistical technique that compares the multiple dependent variables and multiple independent variables. PLS is a misinterpretation of variance-based SEM methods designed to solve multiple regressions when specific problems occur in the data, such as small sample sizes, missing data and multicollinearity. Parameter estimated obtained through PLS can be categorized into three. First, the weight estimate was used to create a latent variable score. Second, reflecting the path estimate (path estimate) that connects latent variables and between latent variables and their indicators (loading). Third, related to the means and location parameters (regression constant values) 
for indicators and latent variables. In order to obtain these three estimates, PLS used a 3-stage iteration process and each iteration stage produces an estimate. The first stage produced a weight estimation, the second stage produces estimation for the inner model and outer model, and the third stage produced an estimation of means and location.

\section{RESULTS AND DISCUSSION}

The results of the study are presented through the results of data processing obtained using instruments in the form of questionnaires both descriptively and inferentially. The first data analysis was done descriptively by using the average value as a description of the tendency of the respondents' assessment concerning the research variables which include: performance, altruism, satisfaction, job characteristics, transformational leadership and organizational commitment. After the descriptive analysis, it was continued with an inferential analysis using structural equation modeling (SEM) analysis technique $[14,15,16]$. SEM testing was done aiming to test the research model and research hypothesis.

\section{Research Model Using Partial Least Square (PLS)}

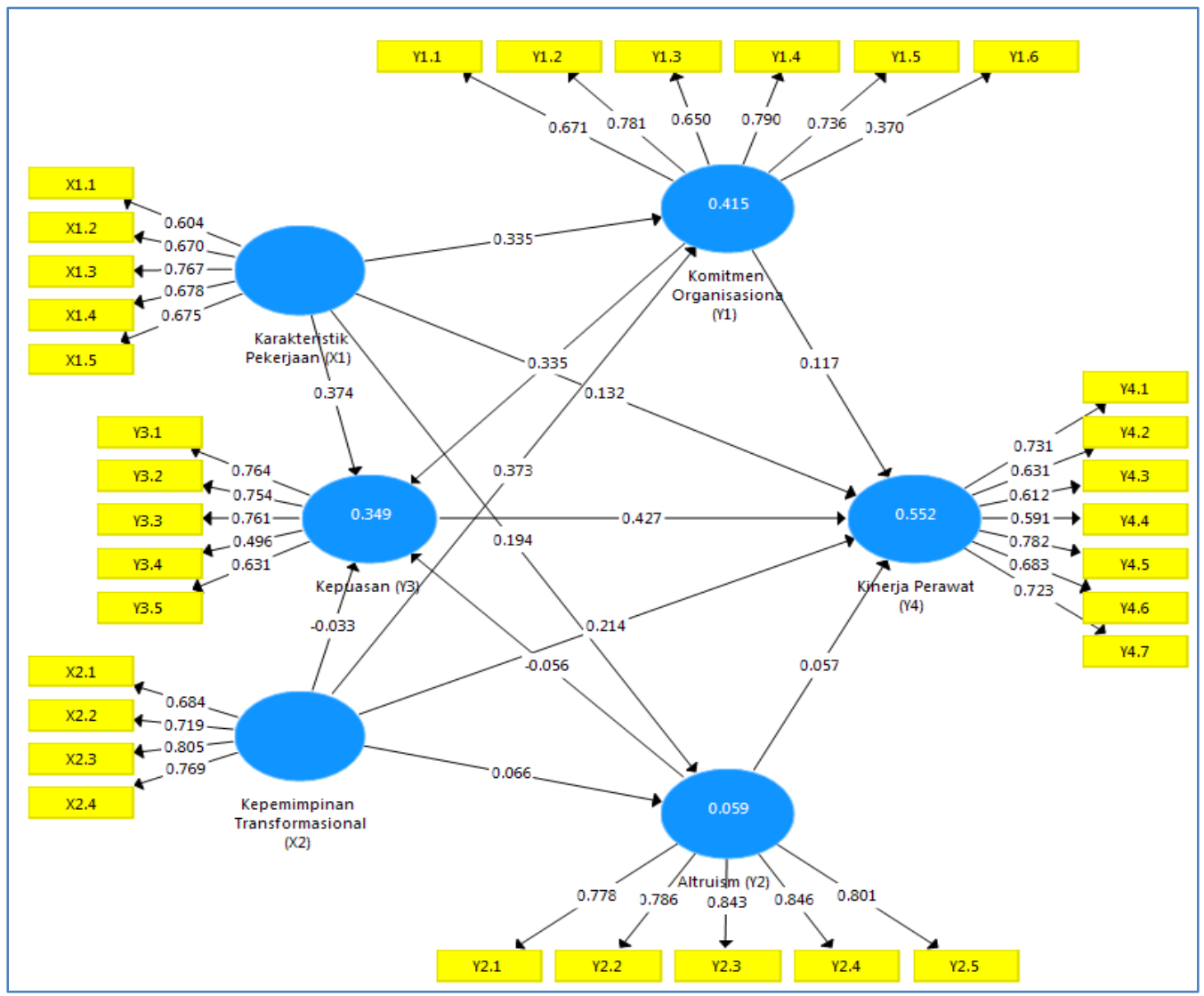

Fig-1: Early Research Model (Elimination I)

The research model of loading factor requirements above 0.50 reflects the loading factor that describes the variables. The initial research model can be seen that there was a construct on the variable loading factor below 0.5 . Based on these criteria, indicators whose loading value was less than 0.50 were eliminated from the analysis. Based on the loading factor values for each indicator of several variables, a new research model was obtained as shown in Figure 2. 


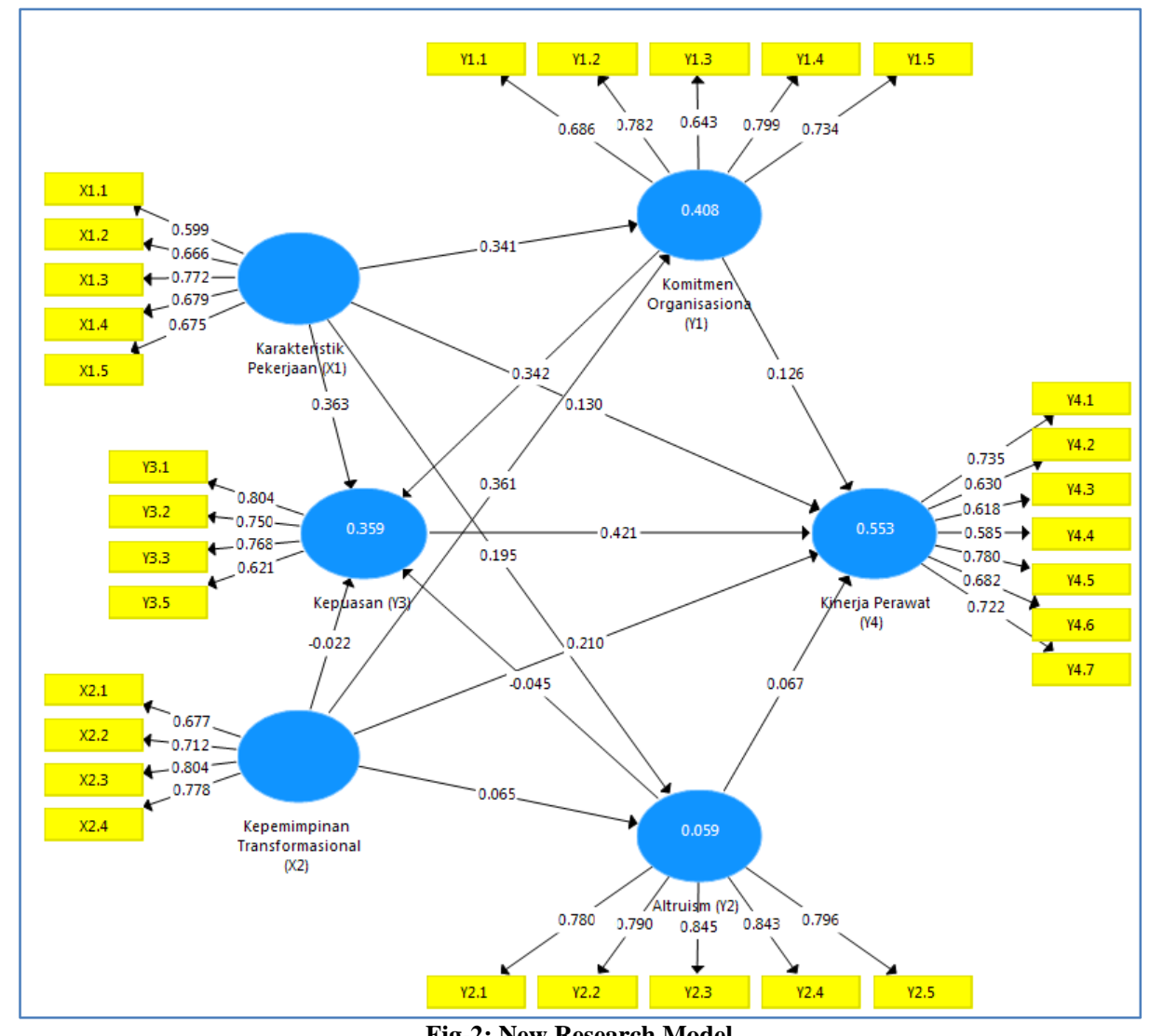

Based on the picture, it appears that all loading factors were 0.50 so that research can proceed to analyze the measurement model or outer model and structural model or inner model.

\section{T-test}

Structural equations explain the effect of exogenous variables on endogenous variables. There are two exogenous functions to endogenous which are explained in the research model, which can be seen in Table 1.

Table-1: The effect of exogenous variables on endogenous variables

\begin{tabular}{|c|c|c|c|c|c|}
\hline & $\begin{array}{c}\text { Original } \\
\text { Sample }\end{array}$ & $\begin{array}{c}\text { Sample } \\
\text { Mean }\end{array}$ & $\begin{array}{c}\text { Standard } \\
\text { Deviation }\end{array}$ & T Statistics & P Values \\
\hline Job characteristics $\rightarrow$ organizational commitment & 0.341 & 0.339 & 0.075 & 4.515 & 0.000 \\
\hline Job characteristics $\rightarrow$ Nurses' satisfaction & 0.363 & 0.365 & 0.084 & 4.295 & 0.000 \\
\hline Job characteristics $\rightarrow$ performance & 0.130 & 0.128 & 0.070 & 1.851 & 0.065 \\
\hline Job characteristics $\rightarrow$ Altruism & 0.195 & 0.202 & 0.091 & 2.134 & 0.033 \\
\hline Transformational leadership $\rightarrow$ organizational & 0.361 & 0.367 & 0.070 & 5.172 & 0.000 \\
\hline commitment & -0.022 & -0.024 & 0.085 & 0.264 & 0.792 \\
\hline Transformational leadership $\rightarrow$ Nurses satisfaction & 0.210 & 0.212 & 0.064 & 3.288 & 0.001 \\
\hline Transformational leadership $\rightarrow$ Performance & 0.065 & 0.074 & 0.096 & 0.680 & 0.497 \\
\hline Transformational leadership $\rightarrow$ Altruism & 0.342 & 0.348 & 0.073 & 4.662 & 0.000 \\
\hline Organizational commitment $\rightarrow$ Nurses' satisfaction & 0.126 & 0.128 & 0.065 & 1.956 & 0.051 \\
\hline Organizational commitment $\rightarrow$ Performance & -0.045 & -0.045 & 0.060 & 0.744 & 0.457 \\
\hline Altruism $\rightarrow$ Nurses' satisfaction & 0.067 & 0.065 & 0.053 & 1.253 & 0.211 \\
\hline Altruism $\rightarrow$ Performance & 0.421 & 0.422 & 0.058 & 7.276 & 0.000 \\
\hline Nurses' satisfaction $\rightarrow$ Performance & & &
\end{tabular}

Source: Output SmartPLS

Based on the Table, it can be seen the positive effect and the level of significance of each variable. If t-Statistic $>1.96$, it means that exogenous variables have a significant effect on endogenous variables and if t-Statistic <1.96, exogenous variables give insignificant effect on endogenous variables with the following explanation:

- Job characteristics have a positive and significant effect on organizational commitment of the nurses at Private Hospitals in Samarinda City

- Job characteristics have a positive and significant effect on the nurses' satisfaction in Private Hospitals in Samarinda 
City

- Job characteristics have a positive but not significant effect on the nurses' performance in Private Hospitals in Samarinda City

- Job characteristics have a positive and significant effect on the nurses' altruism in Private Hospitals in Samarinda City

- Transformational leadership has a positive and significant effect on the organizational commitment of nurses in Private Hospitals in Samarinda City

- Transformational leadership has a negative and insignificant effect on the nurses' satisfaction in Private Hospitals in Samarinda City

- Transformational leadership has a positive and significant effect on the nurses' performance in Private Hospitals in Samarinda City

- Transformational leadership has a positive but not significant effect on the nurses' altruism in Private Hospitals in Samarinda City

- Organizational commitment has a positive and significant effect on the nures' satisfaction in Private Hospitals in Samarinda City

- Organizational commitment has a positive and significant effect on nurses' performance in Private Hospitals in Samarinda City

- Altruism has a negative and not significant effect on the nurses' satisfaction in Private Hospitals in Samarinda City

- Altruism has a positive and insignificant effect on the nurses' performance in Private Hospitals in Samarinda City

- Nurse satisfaction gives a positive and significant effect on the nurses' performance in Private Hospitals in Samarinda City

\section{ConClusion AND RECOMMENDATIONS}

\section{Conclusion}

- Characteristics of work measured through nurses knowing their work well is able to encourage increased organizational commitment of the executive nurses who are measured through nurses not accepting other job offers at Private Hospitals in Samarinda City. This means that if the job characteristics increase, the organizational commitment of nurses at the Private Hospital in Samarinda City also increases significantly.

- Job characteristics measured through nurses knowing their work well is able to encourage the increase in nurse satisfaction as measured through nurses feeling satisfied with the salary received. This means that the increase in work characteristics does not have a significant effect on nurse satisfaction at the Private Hospital in Samarinda City.

- Job characteristics measured through nurses knowing their work well has not been able to encourage the increase in nurses' performance as measured through nurses feel comfortable working with coworkers which means that improving job characteristics does not have a significant effect on nurses' performance at Private Hospitals in Samarinda City.

- Job characteristics measured through nurses knowing their work well are able to encourage the increase in nurse altruism as measured through nurses helping new nurses directly even though they are not needed at Private Hospitals in Samarinda City which means that if job characteristics are improved it will have a real effect on increasing altruism nurse at a Private Hospital in Samarinda City.

- Transformational leadership measured through leadership listening to nurses' aspirations has been able to encourage organizational commitment of nurses as measured through nurses not accepting other job offers at the Private Hospital in Samarinda City. This means that if transformational leadership is improved, it will have a real effect in increasing the organizational commitment of nurses to private hospitals in Samarinda City.

- Transformational leadership as measured through leadership listening to nurses' aspirations has not been able to encourage nurses' satisfaction as measured through Nurses' satisfaction with the current salary of nurses Private Hospitals in Samarinda City which means that increasing transformational leadership does not have a significant effect on reducing nurse satisfaction at Private Hospitals in the city of Samarinda.

- Transformational leadership as measured through leadership listening to nurses' aspirations has been able to encourage the nurses' performance as measured through Nurses comfortable feeling working with colleagues at Private Hospitals in Samarinda City. This means that increasing transformational leadership has a real impact on improving the performance of nurses at Private Hospitals in Samarinda City.

- Transformational leadership as measured by leadership listening to nurses' aspirations has not been able to encourage nurses' altruism as measured through Nurses to help new nurses directly even though it is not needed by the Private Hospital in Samarinda which means that increasing transformational leadership does not have a real impact on increasing nurse altruism in Private Hospitals in Samarinda city.

- Organizational commitment has a positive and significant effect on nurses' satisfaction as measured through nurses feeling satisfied with the current salary of nurses at Private Hospitals in Samarinda City. This means that increasing organizational commitment has a real effect in increasing nurses' satisfaction at Private Hospitals in Samarinda City. 
- Organizational commitment as measured by nurses not accepting other job offers has been able to encourage the performance of nurses as measured through nurses' comfortable feeling working with colleagues at Private Hospitals in Samarinda City. It means that increasing organizational commitment has a real effect in improving the nurses' performance in Private Hospitals in Samarinda City.

- Altruism measured through Nurses helping new nurses directly even though if it is not needed yet has not been able to encourage an increase in nurse satisfaction as measured through Nurses feeling satisfied with the current nurse salary at the Private Hospital in Samarinda City. This means that the increase in altruism has no significant effect on the decrease of nurse satisfaction at the Private Hospitals in Samarinda City.

- Altruism measured through Nurses helping new nurses directly even though if it is not needed yet has not been able to encourage the improvement of nurse performance as measured through Nurses feeling comfortable working with colleagues at Private Hospitals in Samarinda City which means that increasing altruism has a significant effect in improving the nurses' performance at Home Private Hospital in Samarinda City.

- Nurses' satisfaction as measured through nurses are satisfied with the salary of nurses at this time has been able to encourage improved performance of nurses as measured through Nurses feel comfortable working with colleagues at Private Hospitals in Samarinda City. This means that increasing nurse satisfaction does not significantly affect the performance of executive nurses at Private Hospitals in Samarinda City

\section{RECOMMENDATIONS}

- Improving the quality of leadership can be done through selecting leaders whose characteristics are having a good knowledge, can direct subordinates to be able to work properly and correctly, able to communicate both ways with subordinates, have empathy for subordinates, give awards to subordinates who has good work, and able to provide assistance to subordinates whe encountering difficulties in implementing work.

- Increasing organizational commitment to nurses can be done through improving the atmosphere of the relationship between permanent nurses and management, so that the sense of belonging in nurses can still increase and increasing nurses' awareness of the importance of having high loyalty to agencies.

- The results of the analysis of the altruism variable are still in the medium category. This is expected to improve altruism behavior so that hospital goals can be achieved effectively and efficiently. Hospital nurses are expected to be able to increase their participations and be active in activities held by the hospital. A good relationship with colleagues can also continue to be improved so that team performance and work situations become more conducive.

- Nurses are expected to be able to help colleagues who are fatigued. This can create a sense of solidarity among fellow nurses. Nurses are expected to increase the responsibility of carrying out their duties well, friendly and patient in handling patients. The results of the analysis of job satisfaction are mostly still in the medium category. Thus, nurses are expected to be able to build better communication which will improve good relations with the work environment.

- It takes tenacity at work. This provokes managers to give a good assessment of nurses. The results of the analysis on organizational commitment variables are still in the medium category. Hospital nurses are expected to be able to provide good services for patients, nurses are expected to be active in the activities held. Nurses are expected to be able to express their aspirations for the hospital's progress. Nurses are expected to be able to align the values and goals of the hospital with the values that exist in him.

- The hospital needs to reorganize the job characteristics in the hospital because god job caharacteristics can foster the nurses' value which has a direct effect on job satisfaction. Altruism is expected to be able to help new nurses to be able to adapt in their workplaces.

- This research can be used as reference material for future researchers. The author suggests examining the factors that influence OCB, namely procedural justice.

\section{REFERENCES}

1. Budiyanto, M. A. (2015). Penerapan budaya kerja universitas mercu buana di perpustakaan. Universitas Indonesia.

2. Barnes, M., Courtney, M. D., Pratt, J., \& Walsh, A. M. (2004). School- Based Youth Health Nurses: Roles, Responsibilities, Challenges, and Rewards. Public Health Nursing, 21(4), 316-322.

3. Beser, A., Bahar, Z., \& Büyükkaya, D. (2007). Health promoting behaviors and factors related to lifestyle among Turkish workers and occupational health nurses' responsibilities in their health promoting activities. Industrial health, 45(1), 151-159.

4. Crisp, B. R., \& Lister, P. G. (2004). Child protection and public health: nurses' responsibilities. Journal of Advanced Nursing, 47(6), 656-663.

5. Martiningsih, W. (2017). Praktik kolaborasi perawat-dokter dan faktor yang memengaruhinya. Jurnal Ners, 6(2), 147-155.

6. Rumanti, E. (2009). Analisis Pengaruh Pengetahuan Perawat Tentang Indikator Kolaborasi terhadap Praktek Kolaborasi Perawat Dokter di Unit Rawat Inap Rumah Sakit Jiwa Daerah Dr Amino Gondohutomo Semarang. 
Universitas diponegoro.

7. Abidin, M. I. Z., Pongtuluran, Y., \& Maria, S. (2017). Pengaruh kepuasan kerja, lingkungan kerja dan efikasi diri terhdapa komitmen organisasi di rumah sakit smc samarinda. Akuntabel, 13(1), 1-10.

8. Hidayati, T. (2015). Komitmen Organisasi, Kepuasan Kerja, dan Kinerja Karyawan Melalui Pendekatan Kepemimpinan: Studi Terhadap Perawat Beberapa Rumah Sakit Umum di Samarinda. Jurnal Eksekutif, 12(1).

9. Karambut, C. A. (2012). Analisis Pengaruh Kecerdasan Emosional, Stres Kerja dan Kepuasan Kerja terhadap Komitmen Organisasional (Studi pada Perawat Unit Rawat Inap RS Panti Waluya Malang). Jurnal Aplikasi Manajemen, 10(3), 655-668.

10. Koesmono, H. T. (2007). Pengaruh kepemimpinan dan tuntutan tugas terhadap komitmen organisasi dengan variabel moderasi motivasi perawat rumah sakit swasta Surabaya. Jurnal Manajemen dan Kewirausahaan, 9(1), 30-40.

11. Creswell, J. W., \& Hirose, M. (2019). Mixed methods and survey research in family medicine and community health. Family Medicine and Community Health, 7(2), e000086.

12. Johnson, R. B., \& Turner, L. S. (2003). Data collection strategies in mixed methods research. In A. Tashakkori \& C. Teddlie (Eds.). Thousand Oaks, CA: Sage.

13. Brown, T. A. (2014). Confirmatory factor analysis for applied research: Guilford Publications.

14. Hair Jr, J. F., Hult, G. T. M., Ringle, C., \& Sarstedt, M. (2016). A primer on partial least squares structural equation modeling (PLS-SEM): Sage publications.

15. Hair Jr, J. F., Sarstedt, M., Hopkins, L., \& Kuppelwieser, V. G. (2014). Partial least squares structural equation modeling (PLS-SEM). European business review.

16. Ullman, J. B., \& Bentler, P. M. (2003). Structural equation modeling. Handbook of psychology, 607-634. 